Article

\title{
Produce Low Aromatic Contents with Enhanced Cold Properties of Hydrotreated Renewable Diesel Using Pt/Alumina-Beta-Zeolite: Reaction Path Studied via Monoaromatic Model Compound
}

\author{
Shanmugam Palanisamy ${ }^{1, *}$,, Börje Sten Gevert ${ }^{2}$, Pranav Sankaran ${ }^{1}$ and \\ Kannan Kandasamy ${ }^{1, *(D)}$ \\ 1 Department of Chemical Engineering, Kongu Engineering College, Erode 638060, India \\ 2 Kempross AB, Larseredslyckor 14, 42539 Hisingskärra, Sweden \\ * Correspondence: shapal.chem@kongu.edu (S.P.); kannank@kongu.ac.in (K.K.); Tel.:+91-984-282-3432 (K.K.)
}

Received: 18 June 2019; Accepted: 19 July 2019; Published: 24 July 2019

\begin{abstract}
In this present work, Hydro-dearomatisation of toluene and hydro-isomerisation of $\mathrm{n}$-hexadecane ( $\mathrm{n}-\mathrm{C}_{16}$ ) in ultralow sulphur diesel (ULSD) using Pt-Cl/H-Beta and $\mathrm{Pt} / \mathrm{H}$-Beta catalyst was investigated in a continuous down-flow trickle-bed reactor (DFTBR), and the physicochemical properties of products were studied. The catalytic effect on 40:60 wt \% of $H$-beta-zeolite $(H-\beta)$ and binder-aluminahydrochlorite extruded was characterized in scanning electron microscopy, nitrogen adsorption and coke testing. The study showed that 80 to $95 \mathrm{wt} \%$ of middle distillates recovered in ULSD on elevated temperature between 230 and $270{ }^{\circ} \mathrm{C}$ at $5 \mathrm{MPa}$. With a higher residence time of feed, the middle distillate recovered with $2.2 v / v \%$ of aromatics and $-32{ }^{\circ} \mathrm{C}$ of cloud point. In the model compound investigation of toluene and $\mathrm{n}-\mathrm{C}_{16}$, it was observed that absorption of aromatic ring inhibits the rate of isomerisation; particularly it reduces the yield of branching and rearrangement of $\mathrm{n}-\mathrm{C}_{16}$. Also, $\mathrm{Cl}$-incorporated $\mathrm{H}-\mathrm{\beta}$ extrudate enhanced the ring saturation and suppressed the reaction path in oligomerisation and cyclisation of paraffin. This methodology achieved asingle-stage upgrading technique involved in the delivery of commercial diesel in the market with low cloud point and aromatic content.
\end{abstract}

Keywords: hydro-isomerisation; hydrocracking; dearomatisation; diesel; $H$-beta-zeolite

\section{Introduction}

The growing infrastructure and industrialisation lead to high demand for transportation fuel in commercial vehicles. Diesel and light gas oil (LGO) used as the primary transportation fuel [1-3]. As the dependency on conventional diesel marginally increases, the need for additional fuel source for sustaining the market has to identify. In such a case, refineries are interested in substituting biobased transportation fuels like tall-oil, animal fat, fatty acid methyl ester (FAME), or vegetable oil blended with diesel [1-3]. In this context, either blending of FAME with diesel or direct hydrotreated FAME and vegetable oil produce higher-end straight-chain hydrocarbons like heptadecane $\left(C_{17}\right)$ and octadecane $\left(C_{18}\right)$, and the product was named ultralow sulphur diesel (ULSD). The $C_{17}$ and $C_{18}$ influence quick solidification at low temperatures and affects cold filter plugging point (CFPP) [1-9]. Table 1 represents the properties of hydrotreating $5 \mathrm{wt} \%$ FAME blended with diesel, which produces ULSD less than $1 \mathrm{ppm}$ of $\mathrm{S}$ content, $10 \mathrm{vol} \%$ aromatic content and $-32{ }^{\circ} \mathrm{C}$ cloud point.Similarly, the coprocessing of a higher fraction of FAME in ULSD has to upgrade through branching hydrocarbon (n-alkanes to isoalkanes) by hydro-isomerisation and reduce the aromatic content by hydro-dearomatisation [3]. Here, the hydro-isomerisation is the critical step in which product can improve in cold flow properties 
without modification of cetane number of diesel [4-9]. Hydro-dearomatisation, using the trickle-bed catalytic reactor, had hydrogenation of ring and cleavescarbon-carbon cyclic compounds at moderate temperature $250{ }^{\circ} \mathrm{C}$ in the presences of excess $\mathrm{H}_{2}[5-8]$.

Table 1. Physical properties and chemical composition of the hydrotreated and commercial diesel provided by Preem AB, Sweden. IBP-Initial Boling Point; FBP-Final Boiling Point; ${ }^{\text { }}$ polyaromatic hydrocarbon (PAH) (tri+) should be less than $0.02 \%$ with diesel grade. ${ }^{*}$ Samples were analysed at Preem refinery laboratory, Gothenburg, Sweden under the similar test methods adapted earlier $[2,4,5]$.

\begin{tabular}{|c|c|c|c|}
\hline Parameters & Hydrotreated FAME in Gas Oil (ULSD) & Conventional Diesel (LGO) & Reference Test Method * \\
\hline \multicolumn{4}{|c|}{ Compositions } \\
\hline Aromatic (mono-) (\% v/v) & 9.9 & 5.0 & IP 391 \\
\hline Aromatic (di-) $(\% v / v)$ & 0.2 & 0.1 & IP 391 \\
\hline $\mathrm{PAH}(\operatorname{tri}+)(\% v / v)^{\#}$ & $<0.02$ & $<0.02$ & IP 391 \\
\hline \multicolumn{4}{|c|}{ Liquid Paraffins (wt\%) } \\
\hline Gasoline fraction $\left(<195^{\circ} \mathrm{C}\right)$ & 0.6 & 0 & \\
\hline Diesel fraction $\left(195-300^{\circ} \mathrm{C}\right)$ & 93.2 & 98 & \\
\hline Heavy Fraction $\left(>300^{\circ} \mathrm{C}\right)$ & 6.2 & 2.1 & \\
\hline \multicolumn{4}{|c|}{ Distillation temperature $v / v$ rec. $\left({ }^{\circ} \mathrm{C}\right)$ (SIM-DIST) } \\
\hline IBP & 176 & 196 & ASTM D86 \\
\hline Dist: Temp. at $10 \% v / v$ & 195 & 216 & ASTM D86 \\
\hline Dist: Temp. at $50 \% v / v$ & 202 & 237 & ASTM D86 \\
\hline Dist: Temp. at $65 \% v / v$ & 231 & 245 & ASTM D86 \\
\hline Dist: Temp. at $90 \% v / v$ & 259 & 272 & ASTM D86 \\
\hline Dist: Temp. at $95 \% v / v$ & 289 & 384 & ASTM D86 \\
\hline FBP & 303 & 295 & ASTM D86 \\
\hline \multicolumn{4}{|c|}{ Other Properties } \\
\hline Cloud point $\left({ }^{\circ} \mathrm{C}\right)$ & -32 & -34 & EN ISO 23015:1994 \\
\hline Viscosity at $40^{\circ} \mathrm{C}\left(\mathrm{mm}^{2} / \mathrm{s}\right)$ & 2.083 & 1.909 & EN ISO 3104 \\
\hline Density at $15^{\circ} \mathrm{C}\left(\mathrm{kg} / \mathrm{m}^{3}\right)$ & 820.6 & 821.2 & ASTM D4052-09 \\
\hline Cetane Index & 51.86 & 51 & ASTM D 4737 \\
\hline Nitrogen content (mg/kg) & $<1$ & $<1$ & ASTM D 4629 \\
\hline Sulphur content (mg/kg) & $<1$ & $<1$ & EN ISO 8754 \\
\hline
\end{tabular}

In recent decades, hydro-isomerisation of ULSD by noble metals on acidic solid catalyst like zeolites or silica aluminates in micro- or mesopore structure was used in refineries [6-9]. Zeolite synthesis with different crystalline structure and characteristics had widely studied and, its performance was investigate using hydro-isomerisation and hydrocracking on ZSM, Y-type, $H-\beta$, SAPO and MCM for branching the high molecular weight straight-chain hydrocarbons [6-19]. Product shape selectivity mainly achieved through the crystalline pore structure and molecule size in pore diffusive diameter, but the acidity of catalyst play the main role in product distribution [13-15]. The tuning of the acidic property of zeolite and extrudate was achieved by varying $\mathrm{SiO}_{2} / \mathrm{Al}_{2} \mathrm{O}_{3}$ (or $\mathrm{Si} / \mathrm{Al}$ ) and the operating temperature. The characteristics of the zeolite with alumina extrudate acted as acid catalysts, which undergo carbon-carbon rearrangement and hydrogenation. The noble metal functioned in hydrogenation-dehydrogenation catalytic mechanism [7].

Study on postsynthesis modification by impregnation, deposition, ion exchange and pore-mouth siliceous riming over extruders in tuning acidity with different $\mathrm{Si} / \mathrm{Al}$ ratio was observed in the literature [3-9]. Also, different Si/Al ratio in the framework, ranging from 10 to 150, was identified and its influencing parameter of density and strength of acidic sites were decided on reactivity and selectivity in hydro-isomerisation [9]. Notably, an increase in the Si/Al ratio from 12.5 to 150 of $H-\beta$ zeolite can marginally increase in product yield, multibranching selectivity and thermal stability [9]. Here, conversion in branching skeleton isomerisation affected by robust Lewis acidic site in $\mathrm{O}-\mathrm{Si}-\mathrm{O}$ which induced moderate cracking and deactivation. However, the addition of alumina binder suppresses Lewis acid site number, and further increases the Brønsted acid site number to have moderated acidic strength on the surface [9]. Thepublications observed on protonation of Brønstedacid sites induce hydrogen ions for rebranching and isomerisation processes in high $\mathrm{Si} / \mathrm{Al}$ zeolites [10-18]. The previous study revealed that zeolite makes the transition metal more electrophilic, thus helps the reoxidation of metal during the reaction [19].

On the other hand, doping of $\mathrm{Cl}$ in Pt-ZSM- 5 over the hydro-isomerisation proved the suitability with the required acid site number; reduce the acidic strength and lower its coking [10]. Also, enhanced 
Pt dispersion on Cl-doped ZSM-5 induces higher hydrogenation activity of benzene and cyclohexene into cyclohexane, which is evidence for causing dearomatisation. The $\mathrm{Cl}$ enhanced the ring saturation and suppressed the reaction path in oligomerisation [19]. Also, $\mathrm{Cl}$ acts as a catalytic poison if it substitutes through feed in the form of $\mathrm{HCl}$ [19]; whereas investigating with $\mathrm{F}$ doping shows a low acid site number and low hydrogenation activity as compared to $\mathrm{Cl}[10,11]$. Skeletal isomerisation and conversion increases if $\mathrm{Cl}$ ions introduced into alumina to form Brønsted acid sites [11,12]. The reaction has to perform at low temperatures to improve equilibrium yield and lower chlorine elution.

Thermally stable zeolite like $H-\beta$ prepared with noble metal on extrudate should have longer catalyst lifespan (regenerative capability), produce higher selectivity of desired isomer product and achieve a higher yield with minimum cracking [7-10]. Apart from acidic strength, presences of aromatic content in feed and higher operating temperature can affect the regenerative property of catalyst [20-22]. To minimise the coking, excess $\mathrm{H}_{2}$ feed over catalyst surface and moderate operating temperature are sufficient. Apart from acidity, large or medium pore size was required to avoid secondary cracking [23]. Similarly, large diameter pore zeolite can increases monobranch isomers with low hydrocracking at higher isomerisation selectivity [9-15].

Traditionally, hydrogenation of aromatic compounds in diesel was carried using noble metal on alumina. Hydrogenation of ring mainly initiated between 150 and $200{ }^{\circ} \mathrm{C}$, further increase in temperature substantially enhance dehydrogenation [11-13]. Hence, the required hydro-dearomatisation after hydro-isomerisation can examine, if both hydrogenation and dehydrogenation function were performed in a single-stage over a zeolite at an operating temperature from 200 to $300^{\circ} \mathrm{C}$, with hydrogenation of aromatic compounds depends on moderate temperature $[13,22]$. The fundamental research and understanding in dearomatisation of product through zeolite had not explored widely at hydro-isomerisation condition. Also, dual mechanisms, such as dearomatisation and isomerisation of long straight-chain hydrocarbon, had not been investigated.

The investigation of hydro-dearomatisation and -isomerisation using Pt/alumina- $H-\beta$ catalyst was performed in a continuous trickle-bed reactor, in which extrudatewas prepared with alumina hydrogel binder. Large $\mathrm{SiO}_{2} / \mathrm{Al}_{2} \mathrm{O}_{3}$ ratio $H-\beta$ used with hydrogel (with or without $\mathrm{Cl}$ ) for pellet making process. This investigation consists of hydro-isomerisation of $n-C_{16}$, a model compound of long straight-chain hydrocarbon, over intercrystalline $\mathrm{Cl}$ in $\mathrm{Pt} /$ alumina- $H-\beta$ extrudate catalyst, in which high aromatic content of ULSD compared with non-Cl extrudate. This catalyst examines dearomatisation mechanism while upgrading to achieve improved CFPP (or reduce cloud point) and lowered aromatic content. The catalytic influence in hydrocracking and dearomatisation of monoaromatic hydrocarbons at diesel upgrading illustrated and toluene was a model compound in this investigation.

\section{Materials and Methods}

\subsection{Feed Material}

EN590 diesel feed as named Ultralow Sulphur Diesel (ULSD) contains $10 v / v \%$ aromatic content and has less than 1 ppm of nitrogen (ASTM D4629) and sulphur (EN ISO 8754). Hence, the nitrogen and Sulphur considered as negligible amounts in ULSD. Preem refinery, Sweden, supplied the hydrotreated EN590 diesel (ULSD) from the hydro-desulphurization unit. The ULSD consist of high aromatic content and heavier fraction as compared to LGO, detailed data comparison shown in Table 1. Toluene (anhydrous, purity $99.8 \%$ and $<0.1 \%$ benzene) and $n-C_{16}$ (Reagent plus, $99 \%$ purity and $<1 \%$ lighter hydrocarbons) were purchased from Sigma-Aldrich (Gothenburg, Sweden). The blending of $10 \mathrm{wt} \%$ $\mathrm{n}-\mathrm{C}_{16}$ in ULSD was named as $10 \mathrm{H}-\mathrm{ULSD}$ for further description in this investigation.

\subsection{Zeolite Precursor}

Previously, Zeolite pellets with an appropriate binder like Alumina, Silica and Bentonite were investigated [9,11-13]. Instead of doping $\mathrm{Cl}$ through hydrohalogenation mechanism [10,11], preparing zeolite pellets using chlorine-hydrogel can trap the $\mathrm{Cl}$ in intercrystalline structure. Here, impregnation 
methods were used widely to load the known quantity of metals and promoters on the support surface [12-17]. Also, zeolite dehydrating at calcination temperature between 350 and $500{ }^{\circ} \mathrm{C}$ was optimum; in which agglomeration of the framework can be avoided [5,11-14].

\subsection{Zeolite Extrusion}

Beta Zeolite in hydrogen cation form $(H-\beta)$ with a commercial name as $\mathrm{CP} 811 \mathrm{C}-300$ has $\mathrm{SiO}_{2} / \mathrm{Al}_{2} \mathrm{O}_{3}$ mole ratio of 300 and $0.05 \mathrm{wt} \%$ of $\mathrm{Na}_{2} \mathrm{O}$. Extrusion was made by $\mathrm{H}-\beta$ zeolite with hydrogel such as high purity pseudo-boehmite alumina and aluminium hydroxychloride ( $50 \%$ aqueous solution and $0.6 \mathrm{wt} \%$ $\mathrm{Cl}$ ) at a ratio of 40 (zeolite):60 (binder) $\mathrm{wt} \%$ on an alumina basis. The $\mathrm{Cl}$-based extrudates synthesised by blended using aluminium hydroxychloride hydrogel and cylindrical extrudates obtained in $2 \mathrm{~mm}$ diameter and $5 \mathrm{~mm}$ average length through peptisation. Similarly, non- $\mathrm{Cl}$ catalyst synthesised in an aqueous form of pseudo-boehmite and zeolite were extrudate in cylindrical pellets through peptisation in an acidic medium. The support materials were dried at $110^{\circ} \mathrm{C}$ for $5 \mathrm{~h}$ and calcined at $350{ }^{\circ} \mathrm{C}$ for $6 \mathrm{~h}$. Though ion exchange was preferred in most of the research studies, to obtain highly-loaded Pt and to retain $\mathrm{Cl}$ in the extrudate, the preferred method was impregnation. After drying and calcination, platinum was loaded using tetrammineplatinum (II) nitrate $\left(\mathrm{Pt}\left(\mathrm{NH}_{3}\right)_{4}\left(\mathrm{NO}_{3}\right)_{2}\right)$ by impregnation to reach $2 \mathrm{wt} \% \mathrm{Pt}$ on carrier surface [9]. The catalysts were dried at $110{ }^{\circ} \mathrm{C}$ for $5 \mathrm{~h}$ and calcined at a temperature of $400{ }^{\circ} \mathrm{C}$ for $4 \mathrm{~h}$ in the air.

\subsection{Experimental Procedure}

The experimental analysis consists of a tank for feeding ULSD, dossier pump, cocurrent down-flow trickle-bed reactor (DFTBR), gas meter, product collecting tank, mass flow gas controller, temperature controller with three heating zones and gas collector $[2,24,25]$. The reaction parameter consists Liquid Hourly Space Velocity (LHSV = mln of liquid per ml of catalyst per hour), Gas Hourly Space Velocity $(\mathrm{GHSV}=\mathrm{mln}$ of liquid per $\mathrm{ml}$ of catalyst per hour), Operating Pressure $(\mathrm{P})(\mathrm{MPa})$ and temperature $(\mathrm{T})$ $\left({ }^{\circ} \mathrm{C}\right)$. The investigation was carried out with $\mathrm{Pt}-\mathrm{Cl} / \mathrm{H}$ - $\beta$-zeolite, and $\mathrm{Pt} / \mathrm{H}-\beta$-zeolite on extrudes shape of 1/32-in with properties as mentioned in Tables 2 and 3. The catalyst was loaded at the centre of DFTBR with weight $28.31 \mathrm{~g}(31 \mathrm{~mL})$ in designed length $62.6 \mathrm{~mm}$ and internal diameter $18 \mathrm{~mm}$. Rest of the space in DFTBR filled with $2 \mathrm{~mm}$ Borosilicate glass pellets. The mixture of feed and gas was set to flow down in DFTBR on the cocurrent direction and, periodically, all the products had withdrawn from the product tank. The catalyst was in-situ activated by flashing $\mathrm{H}_{2}$ gas at $\mathrm{GHSV}=1400 \mathrm{mln} /$ (g.cat).hat $350{ }^{\circ} \mathrm{C}$ for $8 \mathrm{~h}$ and placed in a small $\mathrm{N}_{2}$ flow for overnight.

Table 2. Texture properties of zeolite molecular size and extruded catalyst determined by $\mathrm{N}_{2}$ sorption using the BET method.

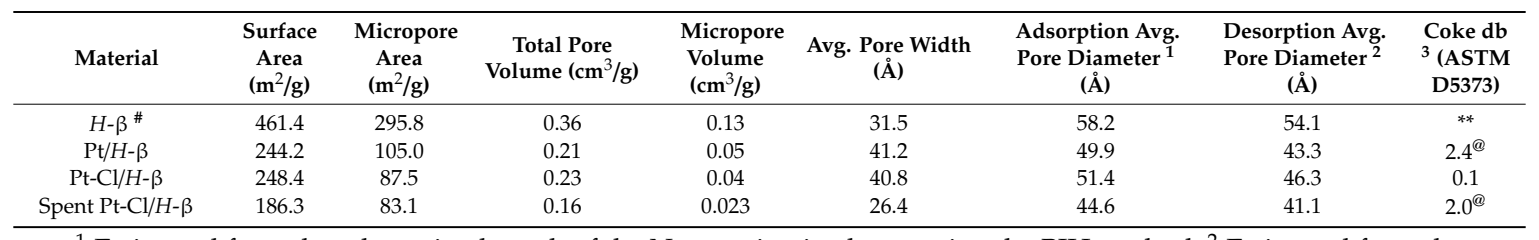

${ }^{1}$ Estimated from the adsorption branch of the $\mathrm{N}_{2}$ sorption isotherm using the $\mathrm{BJH}$ method; ${ }^{2}$ Estimated from the desorption branch of the $\mathrm{N}_{2}$ sorption isotherm using the BJH method; ${ }^{3}$ Analysed by BELAB AB, ASTM 5373 standard test method. $\mathrm{db}=$ dry basis. ${ }^{\circledR}$ Spentcatalyst ( 25 days run) coke measurement, ${ }^{*}$ Molecular sieve $\mathrm{Si} / \mathrm{Al}=100$ (mole basis); ${ }^{* *}$ not available.

\subsection{Analytical Study}

Simulated distillation (ASTM D2887, Gothenburg, Sweden) in gas chromatography (GC) technique (Varian 3400) used to analysis hydro-isomerisation of diesel and $\mathrm{n}-\mathrm{C}_{16}$ liquid product. GC had equipped with a silicon packed column and flame ionisation detector (FID) with a set point and operation procedure as given in the references $[2,24,25]$. The liquid products were analysed in a simple distillation unit based on ASTM D86 standards test method to find the quantitative hydrocarbon fractions. 
Table 3. The composition of elemental metals presents over the section of catalyst surface for segmented Extruder and $\mathrm{Pt}-\mathrm{Cl} / \mathrm{H}$ - $\beta$-zeolite by energy-dispersive spectroscopy (EDS) spectra collected following the SEM technique.

\begin{tabular}{ccccc}
\hline \multirow{2}{*}{ Spectrum Identity (wt\%) } & $\boldsymbol{H}$ - $\boldsymbol{\beta}$ Extruder & \multicolumn{2}{c}{ Pt-Cl/H- $\boldsymbol{~}$} & Pt $/ \mathbf{H}-\boldsymbol{\beta}$ \\
\cline { 2 - 5 } & Top View & Top View & Segmented View & Top View \\
\hline $\mathrm{O}$ & 52.83 & 47.32 & 49.31 & 52.97 \\
$\mathrm{Al}$ & 32.67 & 31.74 & 30.76 & 32.69 \\
$\mathrm{Si}$ & 12.83 & 18.24 & 17.24 & 13.29 \\
$\mathrm{Cl}$ & 1.67 & 0.67 & 0.58 & $* *$ \\
$\mathrm{Pt}$ & $* *$ & 2.03 & 2.11 & 2.05 \\
$\mathrm{SiO}_{2} / \mathrm{Al}_{2} \mathrm{O}_{3}\left(\mathrm{~mol}^{*}\right)^{\#}$ & 0.5 & 0.73 & 0.71 & 0.52 \\
\hline${ }^{* *}$ not available. ${ }^{*}$ ratio denoted as the ratio of estimated moles of silica to moles of alumina.
\end{tabular}

The liquid product in hydro-isomerisation of toluene was performed in a GC connected with mass spectra (Perkin Elmer 3920) equipped with a Capillary column (Elite-5MS column, $30 \mathrm{~m} \times 0.3 \mathrm{~mm}$. I.D., $1.0 \mu \mathrm{m}$ film thickness and dimethyl polysiloxane) and a flame ionisation detector (FID) on $\mathrm{N}_{2}$ as a carrier gas. The injector and detector maintained at $300^{\circ} \mathrm{C}$, and the initial column temperature kept at $40{ }^{\circ} \mathrm{C}$ for $2 \mathrm{~min}$, ramped till $270{ }^{\circ} \mathrm{C}$ at $16^{\circ} \mathrm{C} / \mathrm{min}$ and the final temperature continued for $8 \mathrm{~min}$. Data computation performed using a Hewlett Packard 3380S (Aberdeen, UK) integrator.

The reactor outlet gas line was connected using online Perkin Elmer Clarus GC, signal interprets with 600 link switch controllers, as referred in $[2,24,25]$. The gas analyser consists of a thermal conductivity detector (TCD) to measure $\mathrm{H}_{2}$ and methane, and FID for gaseous hydrocarbon. The inlet and outlet sampling value for FID $\left(\mathrm{N}_{2}\right.$ as mobile phase, at $200^{\circ} \mathrm{C}$ ) and TCD (He as mobile phase, at $250{ }^{\circ} \mathrm{C}$ ) detectors had four valves actuated with programmed pneumatic control by $\mathrm{N}_{2}$ gas in $0.4 \mathrm{MPa}$.

BET surface area measurements on zeolite and its spent materials had performed in a Micro-metrics Surface Area and Porosity Analyser (Tristar 3000, Gothenburg, Sweden) by adsorption of nitrogen. The samples were vacuum-dried at $250^{\circ} \mathrm{C}$ for $2 \mathrm{~h}$ and cooled at room temperature prior analysis.

The freshly prepared zeolite electron microscope (Gothenburg, Sweden), which is equipped with an energy-dispersive $\mathrm{X}$-ray detector for chemical analysis and an electron backscattered diffraction detector, used to identify grain orientation and texture analysis. The catalyst grained in the presence of ethanol solvent and vacuum-dried at $100{ }^{\circ} \mathrm{C}$ for $4 \mathrm{~h}$.

Using Pyridine as probe molecules, concentration of Brønsted and Lewis acid sites was measured for the extrudate in Fourier-transform infrared spectroscopy (FTIR) (Bruker FTIR A. Model Tensor-27, Erode, India) in the transmission mode. With $20 \mathrm{kHz}$ speed and $4 \mathrm{~cm}^{-1}$ spectral resolution, the catalyst of $5 \mathrm{gm}$, which was pressed into thin wafers, was placed in the IR cell after being vacuum-dried at $350{ }^{\circ} \mathrm{C}$ for $2 \mathrm{~h}$. After that the pyridine vapour at $150{ }^{\circ} \mathrm{C}$ is introduced to the cell for $30 \mathrm{~min}$ and hot Argon gas passed for $30 \mathrm{~min}$ then the spectrum is recorded. The presences of Pyridine on surface of catalyst used to study the FTIR spectrum in identification of Brønsted and Lewis acid sites. Also, the amount of acidity in $\mathrm{mmol} / \mathrm{g}$ read with an area of wafer dimension with voidness, the area under the peak in $\mathrm{cm}^{-1}$ and weight of the sample in gram by Lambert-Beer law [26].

Simple distillation, with a cut-off temperature of $170{ }^{\circ} \mathrm{C}$, used to purify upgraded gas oil from hydrocracked lighter fractions. The distillation carried in an $\mathrm{N}_{2}$ atmosphere, and the collected samples had stored in a coolerat $6{ }^{\circ} \mathrm{C}$. The physicochemical properties of ULSD for distilled and nondistilled residual had analysed in Preem refinery (Gothenburg), Sweden.

\section{Results and Discussion}

The feed ULSD was pumped into the reactor by dossier pump on the down-flow direction along with $\mathrm{H}_{2}$ at LHSV $=1 \mathrm{~h}^{-1}, \mathrm{H}_{2}$-GHSV $=1180 \mathrm{mln} /$ (g.cat).h, $\mathrm{P}=5 \mathrm{MPa}$, and $\mathrm{T}=250^{\circ} \mathrm{C}$ for 20 days to achieve stabilised conversion for further experimentation after assuming no coke deposit. Then, maintained from the deactivation/coke deposit stage, the sampling was carried out to examine the 
performance in $H$ - $\beta$-zeolite for the feed that consists of $10 \mathrm{wt} \% \mathrm{n}-\mathrm{C}_{16}$ in ULSD (named as $10 \mathrm{H}$-ULSD). From therein, this research elaborates the analytical study of the isomeric products in forthcoming sections. Each sampling quantity collected for $22 \mathrm{~h}$ run on continuous operation stream.

Mass balance of gases and liquid hydrocarbons were calculated based on carbon molecules; hence, the accuracy was greater than $95 \%$ on average. The overall conversion of reactant calculated as

$$
\text { Conversion }=\frac{\mathrm{n}-\text { Hexadecane present in product } \times 100}{\text { total } \mathrm{n}-\text { Hexadecane fed in the feed }}
$$

\subsection{Catalyst Characterization}

The surface texture of zeolite and metal deposition on extruder was examined using Scanning Electron Microscopy (SEM) technique, as depicted in Table 3 and Figure 1. The SEM showed the appearance of pores in the material cross-section, and the surface consists of $\mathrm{Pt}$ and metallic oxides with a range of 0.58 to $0.67 \mathrm{wt} \%$ of $\mathrm{Cl}$ atoms. Also, EDS spectra confirm the pore structure chlorine atoms with metal oxides and Pt. Table 3 indicates EDS spectra on the top side of pellets with $2.03 \mathrm{wt} \%$ $\mathrm{Pt}$ at $\mathrm{Pt}-\mathrm{Cl} / \mathrm{H}-\beta$ and $2.05 \mathrm{wt} \%$ at $\mathrm{Pt} / \mathrm{H}-\beta$ pellet. Hence, the segmented side of pellet-material shows a higher dispersion of $\mathrm{Pt}$ up to $2.11 \mathrm{wt} \%$, though it represents a single point analysis of $\mathrm{Pt}$; however, multiple locations of spectra testing might vary slightly in metal load. Generally, chemical species reside on oxides of $\mathrm{Al}_{2} \mathrm{O}_{3}$ on the surface indicates Brønsted acidic sites and $\mathrm{SiO}_{2}$ influence widely Lewis acidic sites [13-18]. Low Lewis acidic sites indicate the low coke deposition on the catalyst surface $[27,28]$. However, Table 3 shows the $\mathrm{Al}, \mathrm{Si}, \mathrm{O}$ and $\mathrm{Cl}$ composition on the surface of the prepared extrudates, in which $\mathrm{Al}_{2} \mathrm{O}_{3}$ have the same form in the extrudates, while $\mathrm{SiO}_{2}$ has a higher balance in $\mathrm{Pt}-\mathrm{Cl} / H-\beta$. So, this data reveals the high acidic strength on $\mathrm{Pt}-\mathrm{Cl} / \mathrm{H}-\beta$ than $\mathrm{Pt} / \mathrm{H}-\beta$.

The acidic property of prepared zeolite investigated with the pyridine test following the FTIR method. The result is shown in Figure 2, in which the bonding of acidic sites can identify by $\mathrm{N}$-bonding and pi-bonding. The Lewis sites identified at $1425-1465 \mathrm{~cm}^{-1}$ and Brønsted sites identified at $1635-1500 \mathrm{~cm}^{-1}$. Stretch on $-\mathrm{O}-\mathrm{H}$ with $\mathrm{N}$-bonding at pyridine represents the strong implication of Brønsted acidic sites whereas the Lewis sites show lower concentration with N-bonding on the oxides of the material. Apart from N-bonding, Pi-bonding with oxides and metal sites appeared at $1000-1395 \mathrm{~cm}^{-1}$ implies weak strength to hold for higher operating temperature. In comparing $H-\beta$ and $\mathrm{Cl}-H-\beta$, as visible at Figure $2 \mathrm{c}, \mathrm{d}$, the intensity at $1465 \mathrm{~cm}^{-1}$ and $2350 \mathrm{~cm}^{-1}$ indicate a higher concentration of Lewis sites in chlorine availability. Also, the low density of Brønsted sites shown for $\mathrm{SiO}_{2}$ as compared to $\mathrm{Al}_{2} \mathrm{O}_{3}$ can be visible at the intensity of $\mathrm{N}$ - and $\mathrm{C}$-bonding with surface metal and oxides, as noted in Figure 2a,d. In this investigation with referred calculation [26], though high alumina atoms substituted by extrudates, which give mainly Brønsted sites (estimated concentration in $\mathrm{Cl}-\mathrm{H}-\beta$ of $136 \pm 18 \mathrm{mmol} \mathrm{g}^{-1}$ at ambient condition) by total hydroxyl with Pyridine, but low density of metal oxides bonding with Pyridine has implied Lewis acid sites (estimated concentration in $\mathrm{Cl}-\mathrm{H}-\mathrm{\beta}$ of $101.9 \pm 23 \mathrm{mmol} \mathrm{g}^{-1}$ ) over the surface. Generally, pi-bonding with metal site or oxides might induce ring hydrogenation and hydroxyl group with pyridine might induce the isomerisation mechanism. Further study of isomerisation of straight-chain hydrocarbon and hydrogenation of aromatic compound is required to understand the behaviour of catalyst in product formation on tested conditions.

Figure 3a exhibited characteristics of the extrudate as IV-type hysteresis appeared in the case of ink-bottles shapes of the capillaries or deformed tubes with small outlets. Also, according to the BJH (Barrett-Joyner-Halenda) method, adsorption-desorption branches of isotherms in pore size distribution was calculated and displayed in Figure 3b. The pore width varies from 5.2 to $5.8 \mathrm{~nm}$ size, while the spent catalyst has $4.5 \mathrm{~nm}$, which consists of $2 \mathrm{wt} \%$ coke after the experiment. On average pore volume of $0.21(\mathrm{Pt} / H-\beta)$ and $0.23(\mathrm{Pt}-\mathrm{Cl} / \mathrm{H}-\beta)\left(\mathrm{cm}^{3} / \mathrm{g}\right)$, as represented in Table 2, but the pore size distribution in Figure $3 \mathrm{~b}$ shows two different dual model pore structures appeared. In which both have a very narrow pore size distribution, with an average pore diameter of $38 \AA$ and $55 \AA$, respectively. The range of pore structure distinguishes between 20 to $40 \AA$ and 45 to $70 \AA$ have described as minor and marginally wider pore distribution of duel pores range. 


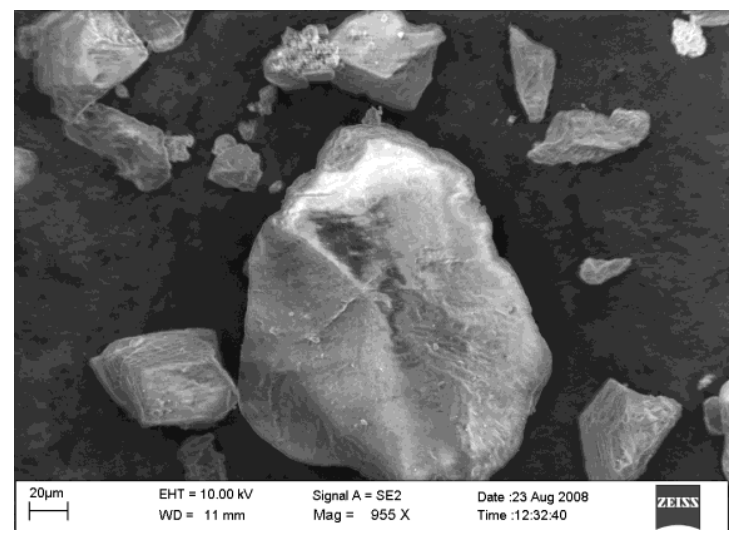

(a)

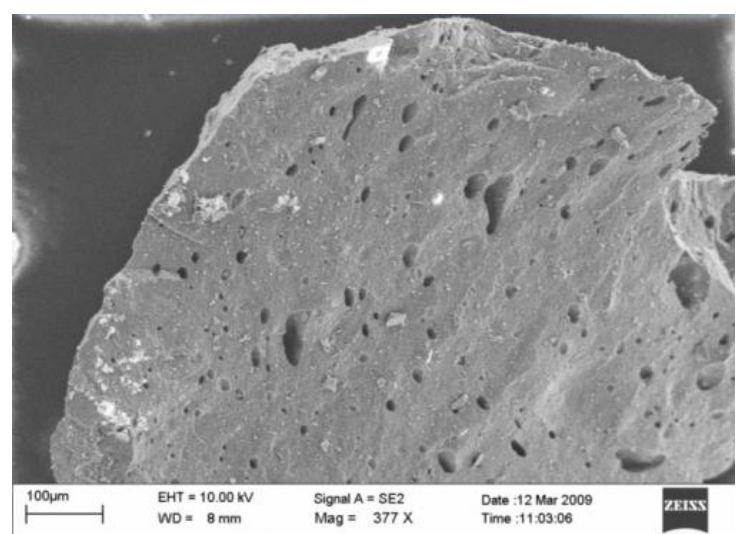

(b)

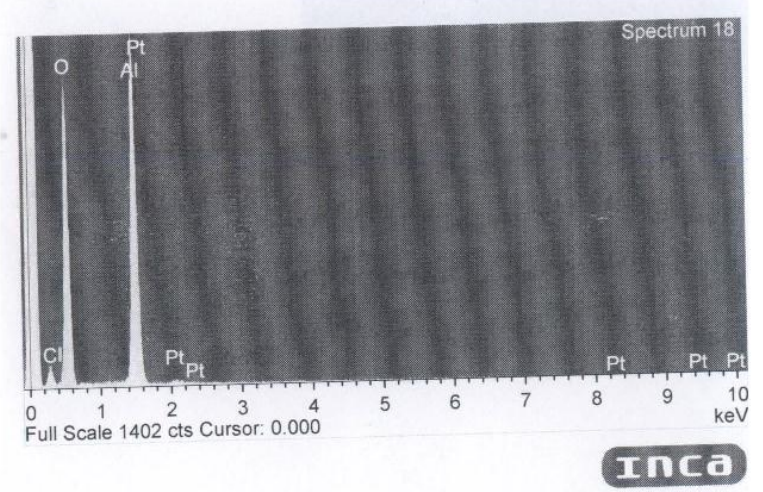

(c)

Figure 1. Two different chlorinated zeolites with extruded morphological exposer with an EDS spectrum: (a) top view; (b) segmented view of catalyst pellet and (c) EDS spectrum of top view.

\subsection{Hydro-Isomerisation of n-Hexadecane in ULSD}

The product of hydro-isomerisation examined for pure $\mathrm{n}-\mathrm{C}_{16}, 10 \mathrm{H}$-ULSD and Toluene on different space velocity, pressure and temperature in specific physicochemical properties shown in Tables 4 and 5 . The feed had tested at an elevated temperature between 200 and $300{ }^{\circ} \mathrm{C}$ under known thermodynamic equilibrium condition, respectively. This moderate condition influences less dehydrogenation and cracking on isomerisation by zeolites [12-17]. 


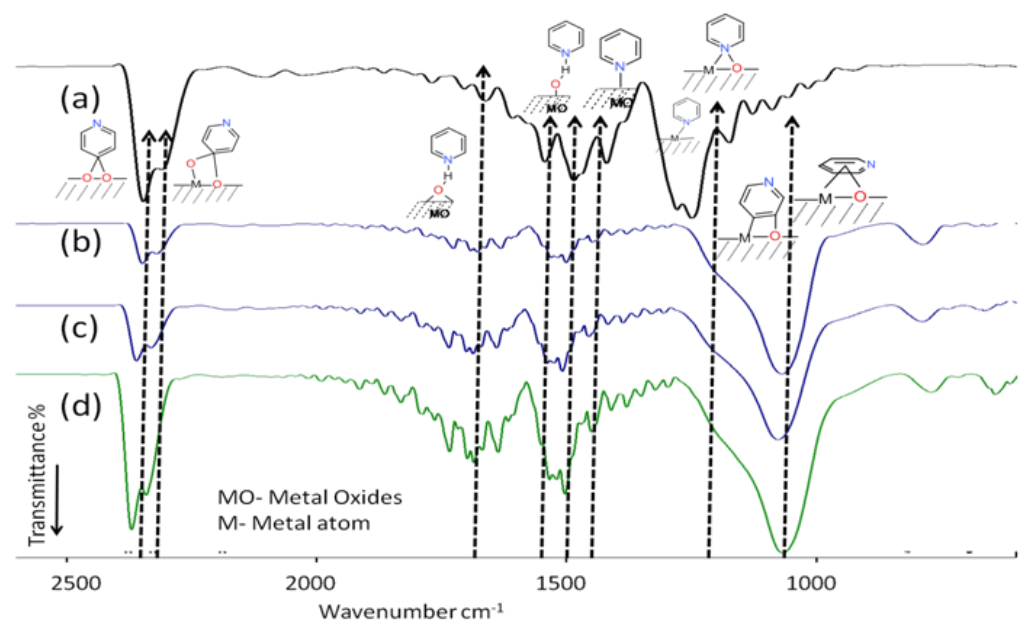

Figure 2. FTIR analysis of zeolites using pyridine as a probe molecule: results consist of (a) $\mathrm{SiO}_{2}$, (b) $\mathrm{Al}_{2} \mathrm{O}_{3},(\mathbf{c}) H-\beta$ and (d) $\mathrm{Cl}-H-\beta$.
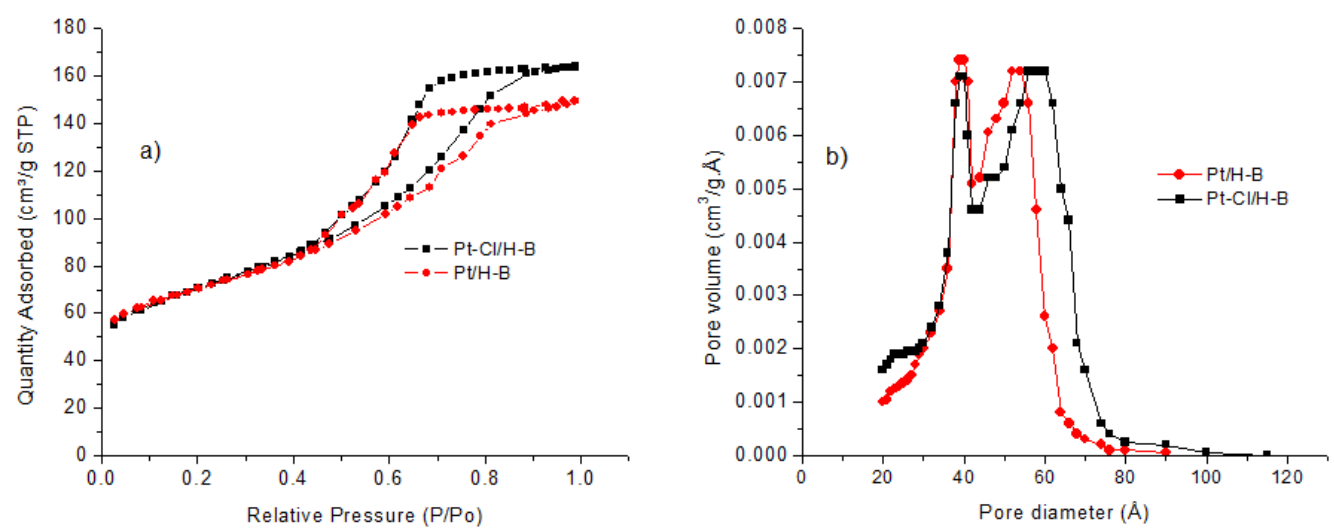

Figure 3. (a) Nitrogen adsorption-desorption isotherm and (b) pore size distribution of $\mathrm{Pt}-\mathrm{Cl} / \mathrm{H}-\beta$ and $\mathrm{Pt} / \mathrm{H}-\beta$ zeolite using the Brunauer-Emmett-Teller method.

Table 4. Physicochemical properties of the hydro-isomerisation product from $10 \mathrm{H}-\mathrm{ULSD}$ by Pt-Cl/H- $\beta$-zeolitein GHSV = $1180 \mathrm{mln} /\left(\right.$ g.cat).h. ${ }^{* *}$ Not available; IBP—Initial Boling Point; FBP—Final Boiling Point; " polyaromatic hydrocarbon (PAH) (tri+) should be less than $0.02 \%$ with diesel grade.

\begin{tabular}{|c|c|c|c|c|c|c|c|c|c|c|c|}
\hline \multirow{2}{*}{ Parameters } & \multirow{2}{*}{$10 \mathrm{H}-$-ULSD } & \multicolumn{5}{|c|}{$\begin{array}{c}\mathrm{P}(\mathrm{MPa}) \text { at } \mathrm{T}\left({ }^{\circ} \mathrm{C}\right)=240^{\circ} \mathrm{C} \text { and } \\
\text { LHSV }=1.0 \mathrm{~h}^{-1}\end{array}$} & \multicolumn{5}{|c|}{$\mathrm{T}\left({ }^{\circ} \mathrm{C}\right)$ at $\mathrm{LHSV}=0.5 \mathrm{~h}^{-1}$ and $\mathrm{P}=5 \mathrm{Mpa}$} \\
\hline & & 4.0 & 4.5 & 5.0 & 5.5 & 6.5 & 230 & 240 & 250 & 260 & 270 \\
\hline Aromatic (mono-) $(\% v / v)$ & 8.8 & ** & 4.5 & 3.8 & ** & 3.3 & 5.6 & 4.9 & 2.2 & $<0.1$ & $<0.1$ \\
\hline Aromatic (di-) (\% v/v) & 0.2 & ** & 0.1 & 0.1 & ** & 0.1 & 0.2 & 0.1 & 0.1 & $<0.1$ & $<0.1$ \\
\hline $\mathrm{PAH}(\operatorname{tri}+)(\% v / v)^{\#}$ & $<0.02$ & ** & $<0.02$ & $<0.02$ & $* *$ & $<0.02$ & $<0.02$ & $<0.02$ & $<0.02$ & $<0.02$ & $<0.02$ \\
\hline \multicolumn{12}{|c|}{ Liquid Products in Boiling Point Range (Temperature in $\left.{ }^{\circ} \mathrm{C}\right)(w t \%)$} \\
\hline Gasoline fraction $(<195)$ & 11.1 & 12.7 & 14.8 & 15.1 & 15.8 & 17.3 & 11.8 & 16.4 & 26 & 38.7 & 47.6 \\
\hline Diesel fraction (195-300) & 85.8 & 85.6 & 83.3 & 83.2 & 82.5 & 81.4 & 83 & 82.7 & 74 & 61.4 & 52.4 \\
\hline Heavy Fraction $(>300)$ & 3.1 & 1.8 & 1.8 & 1.7 & 1.7 & 1.3 & 5.2 & 0.9 & 0 & 0 & 0 \\
\hline \multicolumn{12}{|c|}{ Distillation Temperature $v / v$ Recovery $\left({ }^{\circ} \mathrm{C}\right)$ (SIM-DIST) } \\
\hline IBP & 182 & 183 & ** & 180 & 189 & 189 & 179 & 178 & 177 & 175 & 175 \\
\hline $10 \% v / v$ & 191 & 188 & ** & 194 & 196 & 199 & 187 & 187 & 186 & 185 & 185 \\
\hline $50 \% v / v$ & 216 & 233 & ** & 234 & 237 & 238 & 231 & 231 & 233 & 235 & 235 \\
\hline $65 \% v / v$ & 237 & 249 & ** & 251 & 261 & 270 & 248 & 248 & 247 & 248 & 265 \\
\hline $90 \% v / v$ & 245 & 276 & ** & 275 & 280 & 283 & 276 & 276 & 274 & 274 & 273 \\
\hline $95 \% v / v$ & 289 & 283 & $* *$ & 287 & 285 & 288 & 285 & 289 & 285 & 282 & 280 \\
\hline FBP & 309 & 306 & $* *$ & 301 & 295 & 290 & 302 & 299 & 296 & 291 & 290 \\
\hline \multicolumn{12}{|c|}{ Other Properties for Distilled Product } \\
\hline Cloud point $\left({ }^{\circ} \mathrm{C}\right)$ & 1 & -24 & -21 & -20 & -20 & -22 & -20 & -25 & -32 & -34 & -35 \\
\hline Viscosity at $40^{\circ} \mathrm{C}\left(\mathrm{mm}^{2} / \mathrm{s}\right)$ & 2.1 & 2.0 & 2.0 & 1.9 & 1.9 & 1.9 & 2.0 & 2.0 & 1.9 & 1.9 & 1.9 \\
\hline Density at $15^{\circ} \mathrm{C}\left(\mathrm{kg} / \mathrm{m}^{3}\right)$ & 823.7 & 819.5 & 819.4 & 819.3 & 819 & 818.6 & 821.3 & 820.3 & 812.5 & 804 & 798 \\
\hline
\end{tabular}


Table 5. Physicochemical properties of the hydro-isomerisation by $\mathrm{Pt} / \mathrm{H}-\beta$-zeolite on $\mathrm{T}=240{ }^{\circ} \mathrm{C}$ at $\mathrm{P}=5 \mathrm{Mpa}$ and GHSV $=600 \mathrm{mln} /$ (g.cat).h. Note: ${ }^{*} 10 \%$ Toluene in $10 \mathrm{H}-\mathrm{ULSD}$ and ${ }^{\text {\# Poly aromatic }}$ hydrocarbon (PAH) (tri+) should be less than $0.02 \%$ with diesel grade.

\begin{tabular}{|c|c|c|c|c|}
\hline Parameters & $10 \mathrm{H}-U L S D$ & $10 \mathrm{H}-U L S D$ & $10 \mathrm{H}-U L S D$ & $10 \mathrm{H}-\mathrm{ULSD}+\mathrm{T} *$ \\
\hline LHSV $\left(h^{-1}\right)$ & - & 0.5 & 1 & 1 \\
\hline Aromatic (mono-) $(\% v / v)$ & 8.8 & 7.5 & 7.4 & 10.4 \\
\hline Aromatic (di-) $(\% v / v)$ & 0.2 & 3.2 & 0.3 & 0.4 \\
\hline PAH (tri+) $(\% v / v)^{\#}$ & $<0.02$ & 0.08 & 0.03 & 0.02 \\
\hline \multicolumn{5}{|c|}{ Liquid Products in Boiling Point Range (Temperature in $\left.{ }^{\circ} \mathrm{C}\right)(\mathrm{wt} \%)$} \\
\hline$<125$ & 0.0 & 5.9 & 2.9 & 6.2 \\
\hline 125-195 & 5.2 & 14.4 & 17 & 9.3 \\
\hline 196-215 & 9.4 & 9.8 & 9.7 & 9.6 \\
\hline $216-250$ & 36.0 & 32.4 & 30.9 & 32.3 \\
\hline $251-265$ & 19.7 & 16.3 & 17.4 & 19.2 \\
\hline $265-300$ & 23.5 & 19.3 & 20 & 21.3 \\
\hline Heavy Fraction & 6.2 & 1.9 & 2.1 & 2.1 \\
\hline \multicolumn{5}{|c|}{ Other Properties for Distilled Product } \\
\hline Cloud point $\left({ }^{\circ} \mathrm{C}\right)$ & 1 & -21 & -14 & -20 \\
\hline Viscosity at $40^{\circ} \mathrm{C}\left(\mathrm{mm}^{2} / \mathrm{s}\right)$ & 2.1 & 1.9 & 2 & 1.9 \\
\hline Density at $15^{\circ} \mathrm{C}\left(\mathrm{kg} / \mathrm{m}^{3}\right)$ & 823.7 & 820.6 & 819.5 & 819.1 \\
\hline
\end{tabular}

The product distribution for ULSD and $10 \mathrm{H}$-ULSD hydro-isomerisation results indicate that the yield of diesel fraction reduced from 90 to $50 \mathrm{wt} \%$ at elevated temperature $230-270{ }^{\circ} \mathrm{C}$ and LHSV $=1 \mathrm{~h}^{-1}$ with $100 \%$ hexadecane conversion. Also, naphtha steadily increases from 5 to $50 \mathrm{wt} \%$. Hence, with a lower feed rate at $0.5 \mathrm{~h}^{-1}$, beyond operating temperature $\mathrm{T}=260^{\circ} \mathrm{C}$, the drastic increase in the concentration of lighter naphtha with rich gasoline fraction and simultaneous reduction of diesel fraction was noted and this indicated in Table 4.

The $10 \mathrm{H}$-ULSD contains a total aromatic content of $8.8 \mathrm{v} / \mathrm{v} \%$, which had dearomatised to 5.6 and $0.01 v / v \%$ on elevated temperature, and the respective results are shown in Table 4 . Particularly, at LHSV $=1 \mathrm{~h}^{-1}, \mathrm{P}=5.0 \mathrm{MPa}$ and $\mathrm{T}=240^{\circ} \mathrm{C}$, the aromatic content reduced to $4.9 \mathrm{v} / \mathrm{v} \%$. Also, less than $0.02 v / v \%$ of $\mathrm{PAH}$ noted. As compared with the monoaromatic concentration, $\mathrm{PAH}$ and diaromatic content had no significant changes for elevated temperature and pressure. For elevated pressure between 4.0 and $6.5 \mathrm{MPa}$, the substantial reduction in aromatic was 4.5 to $3.3 \mathrm{v} / \mathrm{v} \%$. Though the increase in $\mathrm{H}_{2}$ pressure saturates ring, the effect was limited comparative to operating temperature. The FBP of products found to be $302-290^{\circ} \mathrm{C}$ for operating temperature, and at high pressure showed $306-290^{\circ} \mathrm{C}$ with lesser hydrocarbons in gasoline fraction. The heavy fraction completely disappeared at elevated temperature, and it appears up to $1.8 \mathrm{wt} \%$ at elevated pressure. Similarly, at the above condition, on $\mathrm{Pt} / \mathrm{H}-\beta$ hydro-isomerisation, heavy fraction appeared in the range of 1.9 to $2.1 \mathrm{wt} \%$. At LHSV $=0.5 \mathrm{~h}^{-1}$ in $\mathrm{Pt} / \mathrm{H}-\beta$, the higher quantity of gasoline-type products appeared and its aromatic content had lowered up to $2 v / v \%$. Also, the tested results indicate the decrease of the cloud point up to -14 to $-21{ }^{\circ} \mathrm{C}$. However, $\mathrm{Pt}-\mathrm{Cl} / \mathrm{H}-\beta$ hydro-isomerisation had -20 to $-34{ }^{\circ} \mathrm{C}$ of the cloud point for $\mathrm{T}$ lower than $260^{\circ} \mathrm{C}$. Higher isomeric compound emphasised with lowering the cloud point and higher the diesel fraction, but it significantly appeared in $\mathrm{Pt}-\mathrm{Cl} / \mathrm{H}-\beta$ than $\mathrm{Pt} / \mathrm{H}-\beta$. Thus the disproportionate mechanism of intermediate might have branching than cracking.

\section{3. n-Hexadecane Isomerisation}

Pure $\mathrm{n}-\mathrm{C}_{16}$ fed for the hydro-isomerisation under the following testing condition; $\mathrm{T}=230$ to $270{ }^{\circ} \mathrm{C}$; LHSV $=0.35$ to $1.5 \mathrm{~h}^{-1} ; \mathrm{P}=5 \mathrm{MPa}$ and GHSV $=1180 \mathrm{mln} /(\mathrm{g}$.cat).h; these results were represented in Figure 4. As the temperature increases, the conversion increases from 35.4 to $61.5 \%$. The product consisted of unsaturated $\mathrm{n}-\mathrm{C}_{16}$ and mono-and dimethyl-branched hydrocarbon with the composition of $43.4 \%$ and $24.6 \%$, respectively. Also, the $\Sigma C_{3}$ and $\Sigma C_{5+} / C_{6+}$ in outlet fuel gas from hydro-isomerisation were increasing for temperature, as shown in Figure 5. Thus, gaseous hydrocarbon 
mostly evolved from hydrocracking of isoalkane/ene. Particularly, the indication of cracking identified by evolving methane, which has a range of 2 to $5 \mathrm{~mol} \%$, and whereas the concentration of other outlet gases increased proportionally with temperature. Authors indicate $H-\beta$ zeolite was widely used for hydrocracking and hydro-isomerisation [9] but had unique nature in alkylation or rebranching [27]. At $250^{\circ} \mathrm{C}$, it indicated that the concentration of isomerised products had a higher rate of formation than its consecutive hydrocracking mechanism. However, the isomer distribution was markedly dependent on the conversion rate and flow rate of feed. As the temperature increases (above $250{ }^{\circ} \mathrm{C}$ ), the reaction rate of hydrocracking increases, this results in the formation of lighter hydrocarbon. Previous results showed that for $\mathrm{Si} / \mathrm{Al}$ ratio less than 35 , for $\mathrm{T}>270{ }^{\circ} \mathrm{C}, 40 \mathrm{wt} \%$ in hydrocracking and $80 \%$ conversion of $\mathrm{n}-\mathrm{C}_{16}$ are notable [14-20].

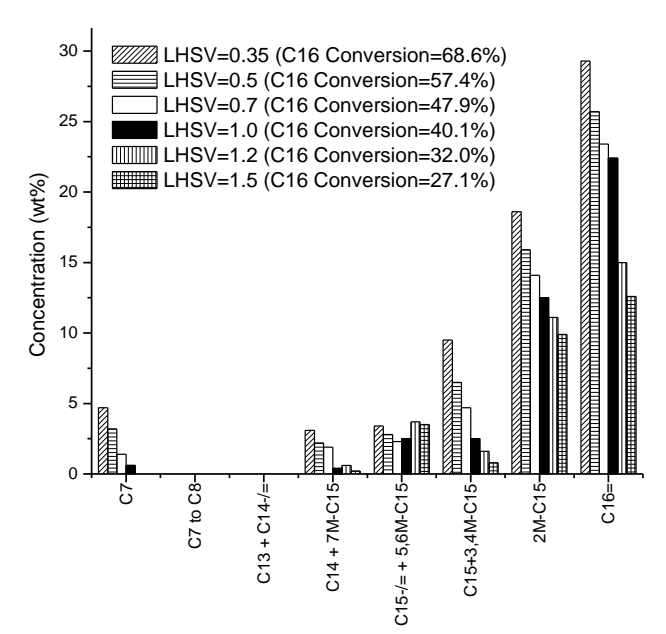

(a)

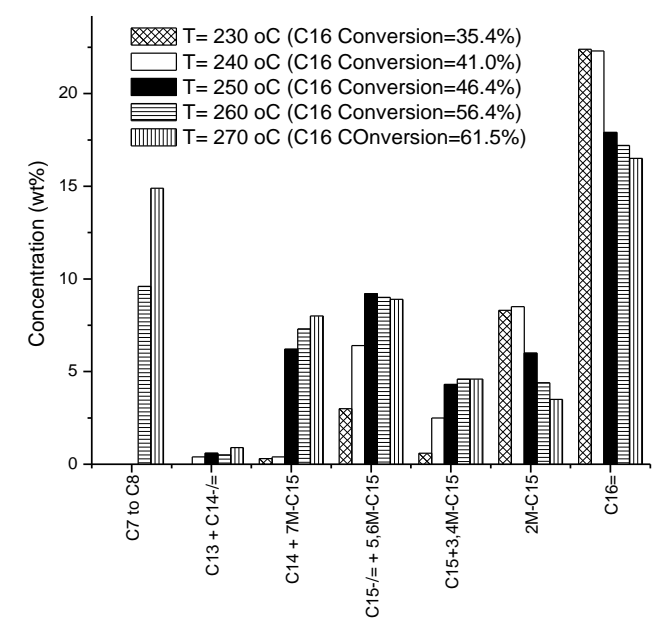

(b)

Figure 4. Product distribution for hydro-isomerisation of $n-C_{16}\left(C_{16}\right)$ by $\mathrm{Pt}-\mathrm{Cl} / \mathrm{H}-\beta, \mathrm{P}=5.0 \mathrm{MPa}$ \& GHSV $=1180 \mathrm{mln} /(\mathrm{g}$.cat).h for (a) different LHSV and (b) different operating temperature (Based on test method ASTM D2887) (Heptane: $C_{7}$, Octane and isomers $\left(\Sigma C_{8}\right): C_{7}$ to $C_{8}$, Tridecane + Tetradecene: $C_{13}+$ $\mathrm{C}_{14-/=}$, Tetradecane +7 -methyl pentadecane+ 4-ethyl pentadecane: $\mathrm{C}_{14}+7 \mathrm{M}-\mathrm{C}_{15}$, Pentadecene $+5 \&$ 6-methyl pentadecane: $\mathrm{C}_{15-/=}+5,6 \mathrm{M}-\mathrm{C}_{15}$, Pentadecane $+3 \&$ 4-methyl pentadecane: $\mathrm{C}_{15}+3,4 \mathrm{M}-\mathrm{C}_{15}$, 2-methyl pentadecane: $2 \mathrm{M}-\mathrm{C}_{15}$, Hexadecene: $\mathrm{C}_{16-/=,} \mathrm{n}$-Hexadecane: $\mathrm{C}_{16}$ ).
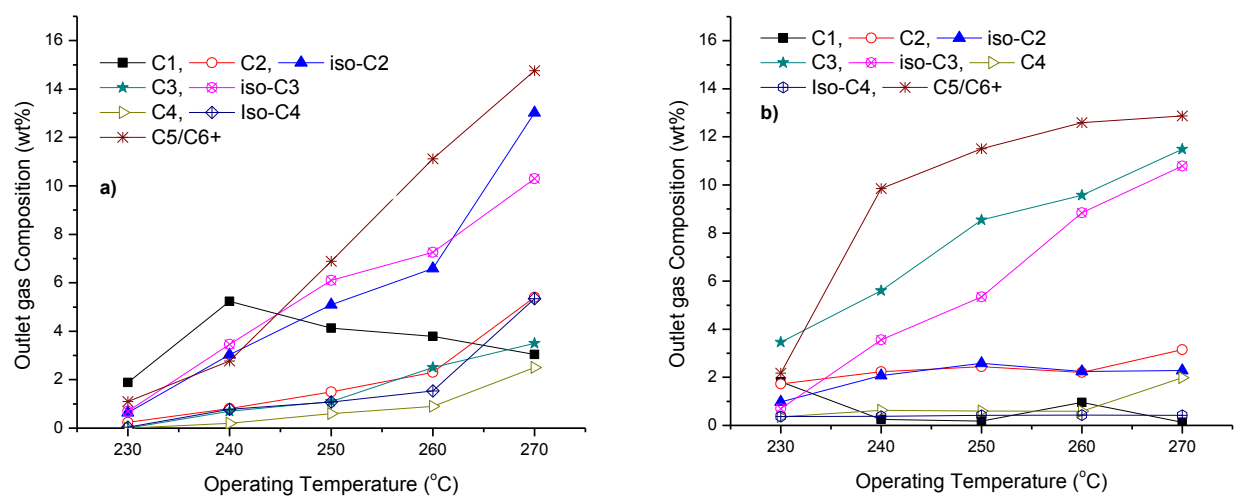

Figure 5. Outlet gas at $\mathrm{P}=50 \mathrm{bar}, \mathrm{LHSV}=1 \mathrm{~h}^{-1} \& \mathrm{GHSV}=1180 \mathrm{mln} /(\mathrm{g}$.cat).h, for different temperature in $\mathrm{Pt}-\mathrm{Cl} / \mathrm{H}-\beta$. (a) feed as $\mathrm{n}-\mathrm{C}_{16}$ and (b) feed as $10 \mathrm{H}-\mathrm{ULSD}$ (note: Mass balance calculated based hydrocarbons and $\mathrm{H}_{2}$ in outlet concentration) (lines to guide eye).

As the liquid flow rate reduced from LHSV $=1.5$ to $0.35 \mathrm{~h}^{-1}$, the conversion increased from $27 \%$ to $68.6 \%$, as represented in Figure 4. The observation indicated that there was limited cracking or methyl group dissociation during rearrangement and branching mechanism. Alkene appeared initially while the secondary carbonium ions initiated the reaction mechanism on metal sites [29]. Hence the $30 \mathrm{wt} \%$ of 
unsaturated alkene formation was seen at LHSV $=0.35 \mathrm{~h}^{-1}$. Also, while increase LHSV, which reduce the residence time of feed on the catalyst, it increase lighter liquid hydrocarbon significantly such as less than $\Sigma \mathrm{C}_{8}$ and the absence of $\Sigma \mathrm{C}_{9}$ to $\Sigma \mathrm{C}_{12}$ noticed. Hence, the bonding of metal and carbonium ion at the $-\mathrm{HC}^{+}-\mathrm{CH}_{3}$ position involved 2-methyl iso group as the initiation of the reaction. The carbonium ion at $\mathrm{C}_{4}$ to $\mathrm{C}_{8}$ position formed with the ion transformation in a chain or proton abstraction to acidic sites of metal. So, the product evolved as $\mathrm{C}_{16}=$ (hexadecene) and $\mathrm{C}_{15-/=}(2 \mathrm{Me}-\mathrm{C} 15)$ which initiate isomeric compounds (alkene show a decrease in the boiling point of below $281^{\circ} \mathrm{C}$, and see at BP $=272{ }^{\circ} \mathrm{C}$ in Tables 4 and 5) which appeared 15 to $30 \mathrm{wt} \%$, as referred in Figure 4 . For LHSV $<1 \mathrm{~h}^{-1}$, the product contains 25 to $30 \mathrm{wt} \%$ of $\mathrm{C}_{16=}$, while on 230 and $270{ }^{\circ} \mathrm{C}$ had 17 to $22 \mathrm{wt} \%$. Also, disproportionate results in hydrocracking for up to $15 \%$ on $\mathrm{T}=270{ }^{\circ} \mathrm{C}$, while no impact by LHSV. The researchers support that hydrocracking on bimetallic zeolite does not affect longer residing hydrocarbon in pore channel [30,31].

On inducing unsaturation in the molecules, there was a shift in reversibility equilibrium on the forward mechanism, so branching of isoalkanes/enes results to $20 \mathrm{wt} \%$ of 2-methyl-pentadecane (2-Me- $\left.\mathrm{C}_{15}\right)$. Further, the propagation of branching appeared in monomethyl group of different positions such as $2-\mathrm{Me}-\mathrm{C}_{15}$ to $7-\mathrm{Me}-\mathrm{C}_{15}$ products. So, the degree of branching had formed in tertiary or higher carbonium ions, but it involved in the dissociation of $-\mathrm{C}-\mathrm{C}^{+}$- by scission with a low degree of hydrogenation at a higher temperature. In this case, excess $\mathrm{H}_{2}$ supply and $2.05 \mathrm{wt} \%$ metal load can influence low hydrocracking $[6,32,33]$. Thus, lower than $10 \mathrm{wt} \%$ of lighter hydrocarbon indicated hydrocracking by $\mathrm{Pt}-\mathrm{Cl} / \mathrm{H}-\beta$ and $\mathrm{Pt} / \mathrm{H}-\beta$. So, with this result of both $10 \mathrm{H}-\mathrm{USLD}$ and $\mathrm{n}-\mathrm{C}_{16}$ isomerisation, it can predict that smaller straight-chain compound might undergo branching in pore channel and longer straight-chain hydrocarbon might undergo branching on the catalyst surface. In terms of pore size, higher the diameter results in secondary cracking but smaller pores had some influences in oligomerisation in relation with previous studies [33].

At higher operating temperatures might redirect the dehydrogenation and alkylation along with thermal cracking.Branched lighter hydrocarbon, as indicated in Figure 5, infers the multibranching subjected to higher hydrocracking. Other than pore structure, temperature and turn over frequency, controlled mechanism over the strength of active sites and catalyst shape selectivity might influences greatly for multibranching. It is complicated to distinguish the branching in USLD. Further, the absence of rings compounds in hydro-isomerisation is reveals that no aromatisation mechanism in isomerisation mechanism.

\subsection{Toluene Dearomatisation}

Hydro-dearomatisation of pure toluene examined with $\mathrm{Pt}-\mathrm{Cl} / \mathrm{H}-\beta$, and $\mathrm{Pt} / \mathrm{H}-\beta$ catalyst can reach up to $45 \mathrm{wt} \%$ conversions, in that $50 \mathrm{wt} \%$ converted into nonaromatic compounds, and its product distribution represented in Figure 6 and its GC-MS results attached in Figure 7. Presence of $7 \mathrm{wt} \%$ of alkylated toluene rings such as 2,2'-dimethyl biphenyl, 3,3'-dimethyl biphenyl and 4,4'-dimethyl biphenyl compounds observed for GHSV $=400 \mathrm{mln} /(\mathrm{g}$.cat).h, but in spite of higher GHSV (1180 $\mathrm{mln} /($ g.cat).h) it vanished in the product (noticed in Figure $6 \mathrm{a}, \mathrm{b})$.

At $240{ }^{\circ} \mathrm{C}, 5.0 \mathrm{MPa}$ and $1180 \mathrm{mln} /(\mathrm{g} . c \mathrm{ct}) . \mathrm{h}$, Hydrogenated rings of alkylated toluene, tetradecane and isomers of tetradecane appeared from $9 \mathrm{wt} \%$ was evident, and the rest contains nearly $37 \mathrm{wt} \%$ hydrocracked compounds without alkylating compounds. For similar condition, $\mathrm{Pt} / \mathrm{H}-\beta$ hydro-dearomatisation results with $7 \mathrm{wt} \%$ of alkylating aromatic compounds, $29 \mathrm{wt} \%$ hydrocracked compounds and rest contain $8 \mathrm{wt} \%$. It indicates $\mathrm{Pt} / H-\beta$ induce alkylation of an aromatic compound on higher concentration.

The alkylation over the cation sites was active, and it also gives heavy distillate products at high temperature through cyclic group rearrangement and dehydrogenation [26,32,33]. At a moderate temperature at $250{ }^{\circ} \mathrm{C}$ and above, the partially cracked radicals from rings initiate in chain growth and, results in unsaturated heavier hydrocarbon. Within chain growth, carbonium ions abstraction $\mathrm{H}^{+}$ proton in secondary alkyl hydrocarbon might shift the placement of double bond as a rearrangement mechanism and also iso-alkenes might make a pathway for alkylation or polymerisation with rings. 
It was evident, from Figure 7, that the toluene undergoes two reaction pathways, first: hydrogenate to cyclic compounds and hydrogenolysis (C-C scission in cyclic group by presence of $\mathrm{H}_{2}$ ) to give iso- $\mathrm{C}_{6}$ isomeric compounds; and second: toluene alkylated into dimethyl biphenyl group, hydrogenated to cyclic compounds and results in the hydrogenolysis to give $\mathrm{C}_{14}$ isomeric compounds. Among other zeolites, $\mathrm{Pt} / \mathrm{H}-\beta$ had the highest absorption of benzene over the surface of active sites [34], this gain in hydrogenation and hydrocracking of the ring, which increases de-aromatise of ULSD feed.
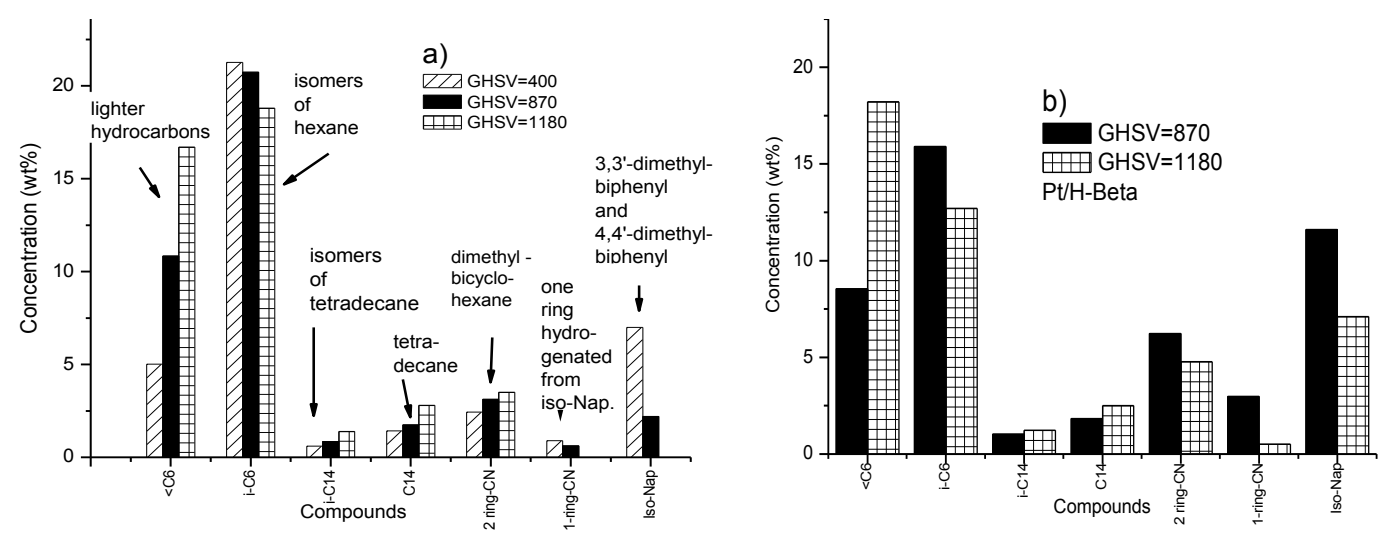

Figure 6. Product distribution for hydro-isomerisation of Toluene, $\mathrm{P}=5.0 \mathrm{MPa}, \mathrm{T}=240{ }^{\circ} \mathrm{C} \&$ LHSV $=1 \mathrm{~h}^{-1}$ for different GHSV (mln/(g.cat).h) (based on test method ASTM D2887) $\left(<\mathrm{C}_{6}\right.$ : lighter hydrocarbons, i-C6:isomers of hexane (iso-hexane), $\mathrm{i}_{-} \mathrm{C}_{14}$ :isomers of tetradecane, $\mathrm{C}_{14}$ : tetradecane, Iso-Nap: 2,2'-dimethyl biphenyl, 3,3'-dimethyl biphenyl and 4,4'-dimethyl biphenyl, 2-ring-CN: two ring hydrogenated from iso-Nap (dimethyl bicyclohexane), 1-ring-CN: one ring hydrogenated from iso-Nap.) (a) Hydro-isomerisation of Toluene using $\mathrm{Pt}-\mathrm{Cl} / \mathrm{H}-\beta$ (b) Hydro-isomerisation of Toluene using $\mathrm{Pt} / \mathrm{H}-\beta$.
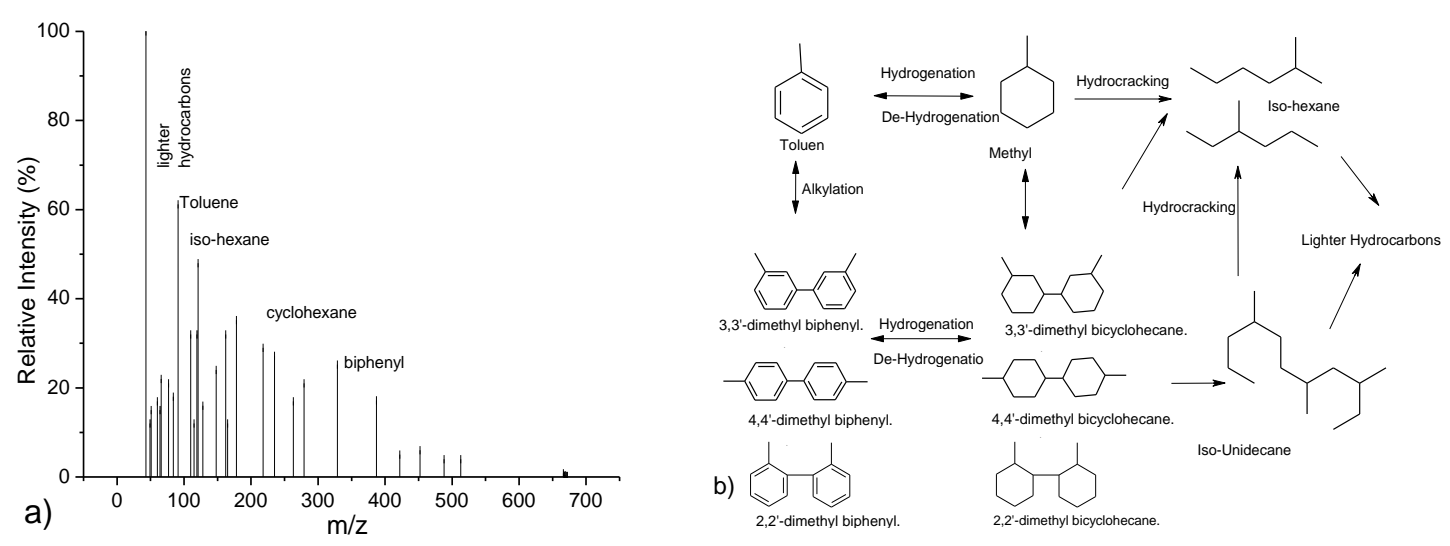

Figure 7. (a) Product distribution for hydro-isomerisation of Toluene using $\mathrm{Pt} / \mathrm{H}-\beta$ at $\mathrm{T}=240{ }^{\circ} \mathrm{C}$, $\mathrm{P}=5.0 \mathrm{MPa}$, LHSV $=1 \mathrm{~h}^{-1}$ and GHSV $=1180 \mathrm{mln} /$ (g.cat).h and (b) Proposed reaction scheme for dearomatisation of Toluene.

Apart from the temperature influences, the dehydrocyclisation of n-paraffins was a metal catalysed reaction [35] that might enhance the aromatisation reaction with metal load and its dispersion over the catalyst surface. Thus, higher dispersed metal situated inside the cages of extrudates favoured in adsorption of aromatics and n-paraffins on the Pt-clusters. Hence, end-on adsorption should facilitate in carbocations to aromatization [11-13]. However, alkylation was unavoidable through $H-\beta$, but in this study, $\mathrm{Pt}$ and $\mathrm{Cl}$ with $\mathrm{H}-\beta$ (more than $2 \mathrm{wt} \% \mathrm{Pt}$ and substituting $\mathrm{Cl}^{-}$with the intercrystalline structure of extrudate) resulted with a significantly low concentration of the bi-phenyl compound. Introducing $\mathrm{Cl}$ in intercrystalline composition weaken acidic strength and this enhanced acid site density and the increase of bond strength within the silica alumina oxides [11]. The chlorinated extrudates contribute to better Pt dispersion in $\mathrm{Pt}-\mathrm{Cl} / \mathrm{H}-\beta$ than $\mathrm{Pt} / \mathrm{H}-\beta$. 
Hydrogenation of rings partially affects by the steric hindrance of the methyl group over the ortho- or para-position with traces of meta-position on phenyl compounds observed. It was also evident the propagation of the methyl group in isomers might shift from ortho- to meta- or paraposition due to the hindering effect [36]. In spite of n-paraffins with aromatic content, inhibition of olefin oligomerisation and multiple alkylations might gain low deactivation on $H-\beta$ [37], which offers oligomerisation of lighter hydrocarbon in benefiting from getting diesel.

\section{Conclusions}

Experimental results indicate that $\mathrm{n}$-alkane can isomerise without significant cracking at 230 and $270{ }^{\circ} \mathrm{C}$ using $\mathrm{Pt}-\mathrm{Cl} / \mathrm{H}-\beta$-zeolite. Since the hydrogenation and its isomerisation independent on the metal content, this reaction over the acid sites was the limiting step of the paraffin transformation. The shift from branches to cracking or disproportionate is low in middle distillate recovery. Further no indication of ring formation in the hydro-isomerisation process. With strong adsorption of toluene on a high binding nature at acidic sites compare to straight-chain hydrocarbons, the hydrogenation and cleavage of $\mathrm{C}-\mathrm{C}$ bond in aromatic show higher rate and thus reduce the composition of aromatic content in the product. So, rearrangement and branching rate had reduced for high aromatic concentration in diesel. The rate of dearomatisation over the acid sites of zeolite was high, and it is temperature-dependent. Subsequently, the reaction rate of hydrocracking was low with the presence of $\mathrm{Cl}$. Therefore, competitive adsorption of aromatic compounds concerning n-paraffins at the acidic sites had reduced isomerisation rate. From this study, monobranched isomeric formation and alkenes reduced the diesel cloud point up to $-32{ }^{\circ} \mathrm{C}$ (say as $250{ }^{\circ} \mathrm{C}$ ). On the other hand, the aromatic content reduced up to $2.2 v / v \%$ was notable.

Author Contributions: Conceptualization, B.S.G.; Data curation, P.S.; Formal analysis, S.P.; Investigation, S.P.; Resources, B.S.G.; Supervision, K.K.; Writing—original draft, S.P.; Writing-review \& editing, K.K.

Funding: This research received no external funding.

Conflicts of Interest: The authors declare no conflict of interest.

\section{References}

1. Reaume, S.J.; Ellis, N. Use of isomerization and hydroisomerization reactions to improve the cold flow properties of vegetable oil-based biodiesel. Energies 2013, 6, 619-633. [CrossRef]

2. Palanisamy, S.; Gevert, B.S. Hydroprocessing of fatty acid methylester containing resin acids blended with gas oil. Fuel Process. Technol. 2014, 126, 435-440. [CrossRef]

3. Liu, C.Y.; Hao, Y.A.N.G.; Jing, Z.Y.; Xi, K.Z.; Qiao, C.Z. Hydrodeoxygenation of fatty acid methyl esters and isomerization of products over NiP/SAPO-11 catalysts. J. Fuel Chem. Technol. 2016, 44, 1211-1216. [CrossRef]

4. Labeckas, G.; Slavinskas, S. Combustion phenomenon, performance and emissions of a diesel engine with aviation turbine JP-8 fuel and rapeseed biodiesel blends. Energy Convers. Manag. 2015, 105, $216-229$. [CrossRef]

5. Kassem, Y.; Camur, H. A laboratory study of the effects of wide range temperature on the properties of biodiesel produced from various waste vegetable oils. Waste Biomass Valoriz. 2017, 8, 1995-2007. [CrossRef]

6. Radlik, M.; Małolepszy, A.; Matus, K. Alkane isomerization on highly reduced $\mathrm{Pd} / \mathrm{Al}_{2} \mathrm{O}_{3}$ catalysts. The crucial role of Pd-Al species. Catal. Commun. 2019, 123, 17-22. [CrossRef]

7. Hancsok, J.; Kovacs, S.; Polczmann, G.; Kasz, T. Investigation the effect of oxygenic compounds on the isomerization of bioparaffins over Pt/SAPO-11. Top. Catal. 2011, 54, 1094-1101. [CrossRef]

8. Zhang, Z.; Pittman, C.U.; Sui, J.S.; Sunand, J.; Wang, Q. Catalytic upgrading of bio-oil by reacting with olefins and alcohols over solid acids: Reaction paths via model compound studies. Energies 2013, 6, 1568-1589. [CrossRef]

9. Gomes, L.C.; Rosas, D.D.O.; Chistone, R.C.; Zotin, F.M.Z.; de Araujo, L.R.R.; Zotin, J.L. Hydroisomerization of n-hexadecane using $\mathrm{Pt} /$ alumina-Beta zeolite catalysts for producing renewable diesel with low pour point. Fuel 2017, 209, 521-528. [CrossRef] 
10. Gläser, R.; Gomm, S.; Weitkamp, J. In situ investigation of cumene synthesis over dealuminated zeolite catalysts by means of a tapered element oscillating microbalance. In Studies in Surface Science and Catalysis; Elsevier: Amsterdam, The Netherlands, 2004; Volume 154, pp. 2125-2132.

11. Aboul-Gheit, A.K.; Awadallah, A.E.; Aboul-Gheit, N.A.K.; Solyman, E.A.; Abdel-Aaty, M.A. Effect of hydrochlorination and hydrofluorination of Pt/H-ZSM-5 and Pt-Ir/H-ZSM-5 catalysts for n-hexane hydroconversion. Appl. Catal. A Gen. 2008, 334, 304-310. [CrossRef]

12. Aboul-Gheit, N.A.K. Effect of hydrohalogenation of metal/zeolite catalysts for cyclohexene hydroconversionPart 3- Pd/H-ZSM-5 catalysts. J. Chin. Chem. Soc. 2007, 54, 1211-1222. [CrossRef]

13. Sidhpuria, K.B.; Parikh, P.A.; Bahadur, P.; Jasra, R.V. Rhodium supported H $\beta$ zeolite for the hydrogenation of toluene. Ind. Eng. Chem. Res. 2008, 47, 4034-4042. [CrossRef]

14. Cui, S.; Wang, G.; Yang, Y.; Liu, B. Influence of Si/Al molar ratio on the hydrogenation, isomerization and ring opening of naphthalene over silica-alumina supported Ni2P catalyst. Fuel 2018, 225, 10-17. [CrossRef]

15. Fan, Y.; Bao, X.; Shi, G.; Wei, W.; Xu, J. Olefin reduction of FCC gasoline via hydroisomerization aromatisation over modified HMOR/HZSM-5/H-beta composite carriers. Appl. Catal. A Gen. 2004, 275, 61-71. [CrossRef]

16. Tian, S.; Chen, J. Hydroisomerization of n-dodecane on a new kind of bifunctional catalyst: Nickel phosphide supported on SAPO-11 molecular sieve. Fuel Process. Technol. 2014, 122, 120-128. [CrossRef]

17. Park, K.C.; Ihm, S.K. Hydroisomerization of n-tetradecane over Pt/SAPO-11 catalyst. Appl. Catal. A Gen. 2000, 203, 201-209. [CrossRef]

18. Geng, C.; Zhang, F.; Gao, Z.; Zhao, L.; Zhou, J. Hydroisomerization of n-tetradecane over Pt/SAPO-11 catalyst. Catal. Today 2014, 93-95, 485-491. [CrossRef]

19. Osman, A.I.; Abu-Dahrieh, J.K.; Rooney, D.W.; Thompson, J.; Halawy, S.A.; Mohamed, M.A. Surface hydrophobicity and acidity effect on alumina catalyst in catalytic methanol dehydration reaction. J. Chem. Technol. Biotechnol. 2017, 92, 2952-2962. [CrossRef]

20. Kubicka, D.; Kikhtyanin, O. Opportunities for zeolites in biomass upgrading-Lessons from the refining and petrochemical industry. Catal. Today 2015, 243, 10-22. [CrossRef]

21. Osman, A.I.; Abu-Dahrieh, J.K.; Abdelkader, A.; Hassan, N.M.; Laffir, F.; McLaren, M.; Rooney, D.W. Silver-Modified $\eta-\mathrm{Al}_{2} \mathrm{O}_{3}$ Catalyst for DME Production. J. Phys. Chem. C 2017, 121, 25018-25032. [CrossRef]

22. Li, X.; Shen, B.; Guo, Q.; Gao, J. Effects of large pore zeolite additions in the catalytic pyrolysis catalyst on the light olefins production. Catal. Today 2007, 125, 270-277. [CrossRef]

23. Wang, Y.; Tao, Z.; Wu, B.; Xu, J.; Huo, C.; Li, K.; Chen, H.; Yang, Y.; Li, Y. Effect of metal precursors on the performance of Pt/ZSM-22 catalysts for n-hexadecane hydroisomerization. J. Catal. 2015, 22, 1-13. [CrossRef]

24. Palanisamy, S.; Gevert, B.S. Hydrodeoxygenation of fatty acid methyl ester in gas oil blend-NiMoS/Alumina. Green Process. Synth. 2017, 7, 260-267. [CrossRef]

25. Palanisamy, S.; Gevert, B.S. Study of non-catalytic thermal decomposition of triglyceride at hydroprocessing condition. Appl. Therm. Eng. 2016, 107, 301-310. [CrossRef]

26. Song, Y.; Lin, W.; Guo, X.; Dong, L.; Mu, X.; Tian, H.; Wang, L. Aromatization and isomerization of methylcyclohexane over Ni catalysts supported on different supports. Green Energy Environ. 2018, 4, 75-82. [CrossRef]

27. Ramos, M.J.; Lucas, A.D.; Jiménez, V.; Sánchez, P.; Valverde, J.L. Hydro-isomerization of different refinery naphtha streams by using a beta zeolite catalyst. Fuel Process. Technol. 2008, 89, 721-727. [CrossRef]

28. Buzetzki, E.; Sidorová, K.; Cvengrošová, Z.; Kaszonyi, A.; Cvengroš, J. The influence of zeolite catalysts on the products of rapeseed oil cracking. Fuel Process. Technol. 2011, 92, 1623-1631. [CrossRef]

29. Ono, Y.A. Survey of the mechanism in the catalytic isomerisation of alkanes. Catal. Today 2003, 81, 3-16. [CrossRef]

30. Soualah, A.; Lemberton, J.; Pinard, L.; Chater, M.; Magnoux, P.; Moljord, K. Hydroconversion of $n$-decane on Pt/HZSM-5 bifunctional catalysts: Effect of the Si/Al ratio of the zeolite on selectivities. React. Kinet. Mech. Catal. 2010, 101, 209-219. [CrossRef]

31. Saxena, S.K.; Viswanadham, N.; Garg, M.O. Cracking and isomerisation functionalities of bi-metallic zeolites for naphtha value upgradation. Fuel 2013, 107, 432-438. [CrossRef]

32. Jaroszewska, K.; Masalska, A.; Czycz, D.; Grzechowiak, J. Activity of shaped Pt/AlSBA-15 catalysts in n-hexadecane hydroisomerization. Fuel Process. Technol. 2017, 167, 1-10. [CrossRef]

33. Ye, G.; Sun, Y.; Guo, Z.; Zhu, K.; Liu, H.; Zhou, X.; Coppens, M.O. Effects of zeolite particle size and internal grain boundaries on Pt/Beta catalyzed isomerization of n-pentane. J. Catal. 2018, 360, 152-159. [CrossRef] 
34. Degnan, J.T.F. Applications of zeolites in petroleum refining. Top. Catal. 2000, 13, 349-356. [CrossRef]

35. Claude, M.C.; Martens, J.A. Monomethyl-Branching of Long n-Alkanes in the Range from Decane to Tetracosane on Pt/H-ZSM-22 Bi-functional Catalyst. J. Catal. 2000, 190, 39-48. [CrossRef]

36. Shi, Q.; Gonçalves, J.C.; Ferreira, A.F.P.; Plaza, M.G.; Rodrigues, A.E. Xylene isomerization side reactions over Beta zeolite: Disproportionation and transalkylation of $C_{8}$ aromatics and toluene. Appl. Catal. A Gen. 2018, 562, 198-205. [CrossRef]

37. Wang, J.J.; Chuang, Y.Y.; Hsu, H.Y.; Tsai, T.C. Toward industrial catalysis of zeolite for linear alkylbenzene synthesis: A mini-review. Catal. Today 2017, 298, 109-116. [CrossRef]

(C) 2019 by the authors. Licensee MDPI, Basel, Switzerland. This article is an open access article distributed under the terms and conditions of the Creative Commons Attribution (CC BY) license (http://creativecommons.org/licenses/by/4.0/). 